\title{
ENVENOMATION CAUSED BY Latrodectus geometricus IN SÃO PAULO STATE, BRAZIL: A CASE REPORT
}

\section{Almeida RAMB (1), Ferreira Junior RS (2), Chaves CR (1), Barraviera B (1, 2)}

(1) Department of Tropical Diseases and Imaging Diagnosis, Botucatu Medical School, São Paulo State University, UNESP, Botucatu, São Paulo State, Brazil; (2) The Center for the Study of Venoms and Venomous Animals, CEVAP, São Paulo State University, UNESP, Botucatu, São Paulo State, Brazil.

ABSTRACT: Widow spiders (Latrodectus spp.), also known as "black widows", have a worldwide distribution and can cause latrodectism. To the best of our knowledge, in Brazil, only one case of Latrodectus geometricus (Koch, 1841) envenomation in a human has been reported. The aim of the present report is to describe a spider bite caused by Latrodectus geometricus in a patient who lives in Paranapanema, São Paulo state, Brazil.

KEY WORDS: Latrodectus geometricus, envenomation, latrodectism, brown widow.

CONFLICTS OF INTEREST: There is no conflict.

\section{CORRESPONDECE TO:}

RICARDO AUGUSTO MONTEIRO DE BARROS ALMEIDA, Departamento de Doenças Tropicais e Diagnóstico por Imagem, Faculdade de Medicina de Botucatu, UNESP, Distrito de Rubião Jr., s/n, Botucatu, SP, 18.618-000, Brasil. Phone: +55 14 3811 6212. Fax: +55 143815 9898. Email: ralmeida@fmb.unesp.br. 


\section{INTRODUCTION}

There are currently 30 recognized Latrodectus species (Theridiidae family), commonly known as widow spiders, which are disseminated throughout the globe. Latrodectism, the clinical syndrome caused by the venom injected via the bite of this species, is characterized by local and generalized pain associated with nonspecific systemic effects, diaphoresis, and, less commonly, other autonomic and neurological effects. Specific antivenom and supportive treatment are recommended mainly in cases of persistent pain or systemic envenomation; and death is rare (1-3).

Although Latrodectus geometricus (Koch, 1841), also called "brown widow", is a spider of urban distribution, accidents involving humans are rare (4). Other Latrodectus genera are worth mentioning due to their highly potent neurotoxin, called $\alpha$-latrotoxin ( $\alpha$-LTX), which induces exhaustive release of which neurotransmitters from vertebrate nerve terminals and endocrine cells $(5,6)$.

In Brazil there has been only one case reported of Latrodectus geometricus envenomation among humans (7). The current study aims to describe a spider bite provoked by Latrodectus geometricus in a patient living in Paranapanema, São Paulo state, Brazil.

\section{CASE REPORT}

A 19-year-old female patient was taken to the emergency room of the Paranapanema Hospital (S 2323'14" W 4843'24"), São Paulo state, Brazil, due to a spider bite. The accident occurred in April (autumn), at 11 a.m., when she was sleeping on a cot, $30 \mathrm{~cm}$ above the ground.

She was awoken by an itch on the medial region of her left forearm. Subsequently, her mother found a dead spider on the victim's blouse. The itching gradually increased in intensity and then erythema appeared at the bite site. Fifteen minutes later, there was local burning pain, papules and increasing erythema.

After 30 minutes, irradiating pain was present on her left arm and shoulder. At that moment, the patient medicated herself with dextrochlorpheniramine maleate associated with betamethasone.

As this strategy produced no recovery, the victim was taken to the emergency room of the Paranapanema Hospital, where she received dipyrone, promethazine and hydrocortisone. Local analgesic block with $1 \%$ lidocaine for pain relief was employed causing temporary improvement. 
In order to confirm the diagnosis, another evaluation was requested from the Tropical Diseases Department of Botucatu Medical School, São Paulo State University, Brazil. So, the patient arrived at the hospital of Botucatu Medical School four hours after the bite presenting local burning. There were no systemic symptoms such as fever, sweating, hypotension/hypertension, palpitations, dyspnea, dizziness, weakness, tremors, muscle spasms or pain, abdominal pain, anxiety, agitation, headache, nausea or emesis.

A $0.3 \mathrm{~cm}$ papular lesion surrounded by a $1.0 \mathrm{~cm}$ hypochromic halo and a $10 \mathrm{~cm}$ external halo with slight swelling was observed (Figure 1). Her systemic blood pressure, heart and respiratory rates were normal, while the physical examination presented no other changes.

Comparing the atypical clinical features with previous accidents in the region, the investigation into the cause of this accident started and assistance was requested from The Center for the Study of Venoms and Venomous Animals of UNESP, CEVAP, Brazil.

Although the spider was badly damaged, we could confirm the initial suspicion that the envenomation had been caused by a Latrodectus geometricus spider (Figures 2 and 3).

The patient was then hospitalized and laboratory tests revealed only a slight nuclear deviation of neutrophils to the left in hematological tests (Table 1). Approximately two hours after the anesthesia, pain reappeared with greater intensity and lidocaine was used many times. Paracetamol, dipyrone and tramadol hydrochloride were also prescribed until the pain wore off. 


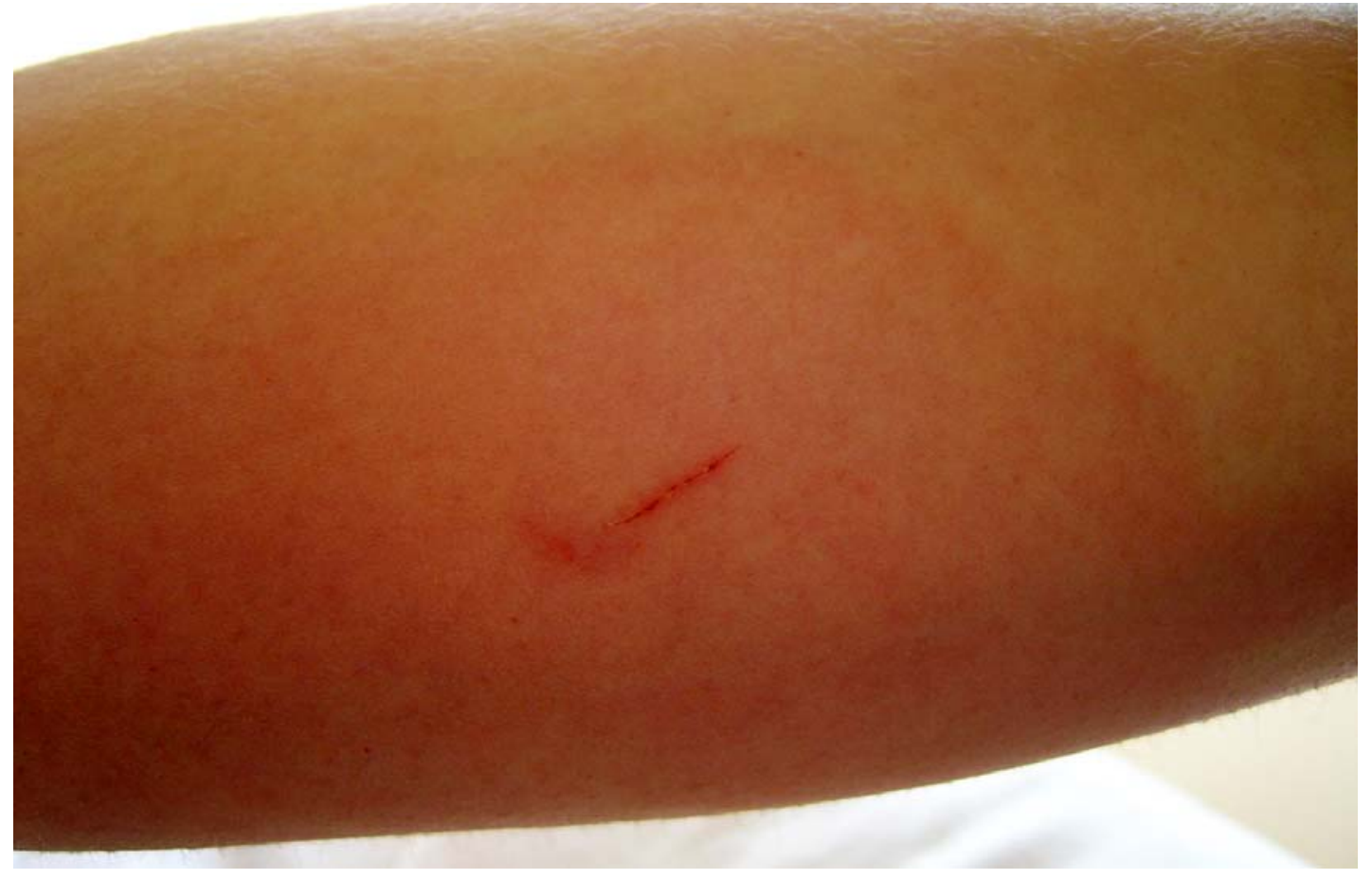

Figure 1. External halo with slight swelling observed on the left forearm, medial region (bite site).

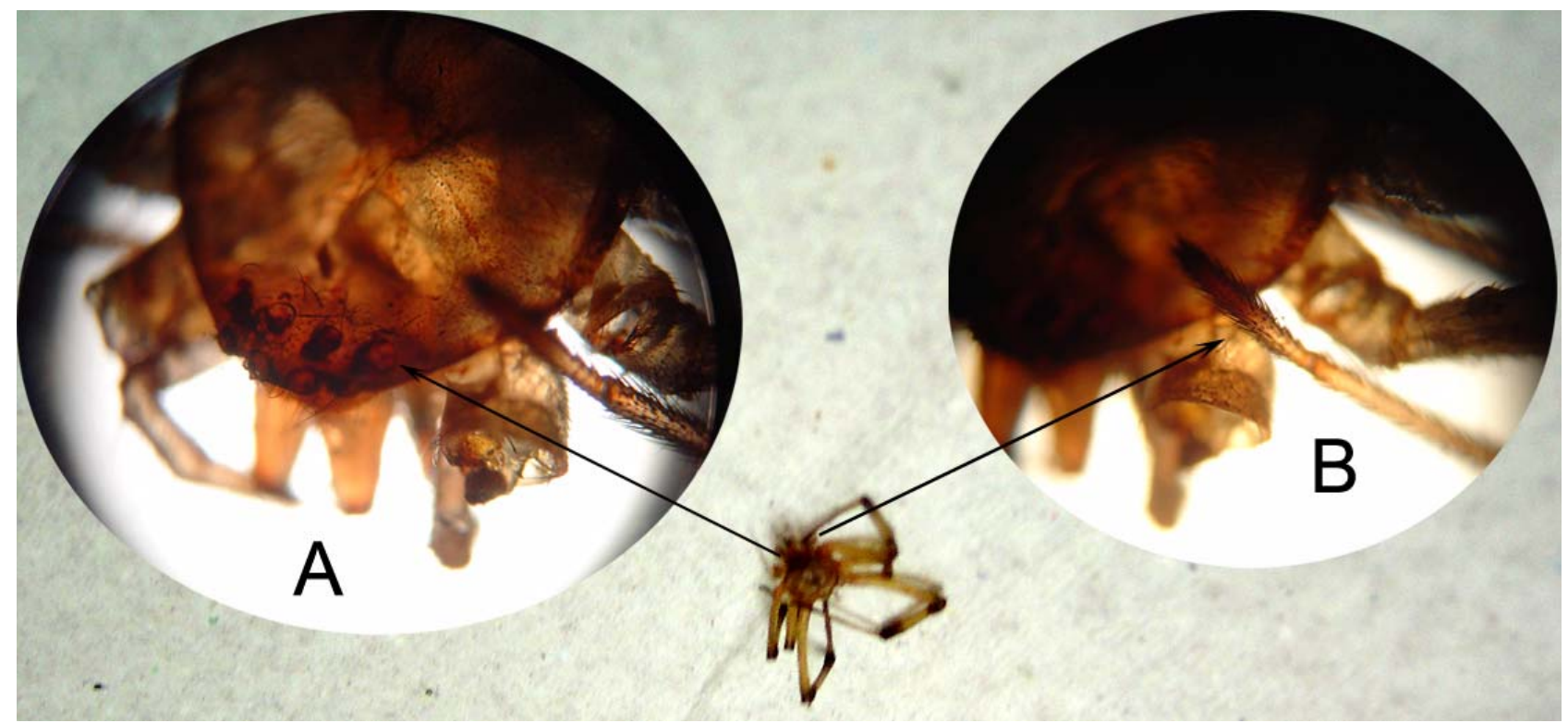

Figure 2. Latrodectus geometricus spider (brown widow) that provoked the accident. Identification through the spider eye arrangement 4:4 (A) and comblike bristles (B). 
Almeida RAMB et al. Envenomation caused by Latrodectus geometricus in São Paulo State, Brazil: a case report. J Venom Anim Toxins incl Trop Dis. 2009;15(3):566

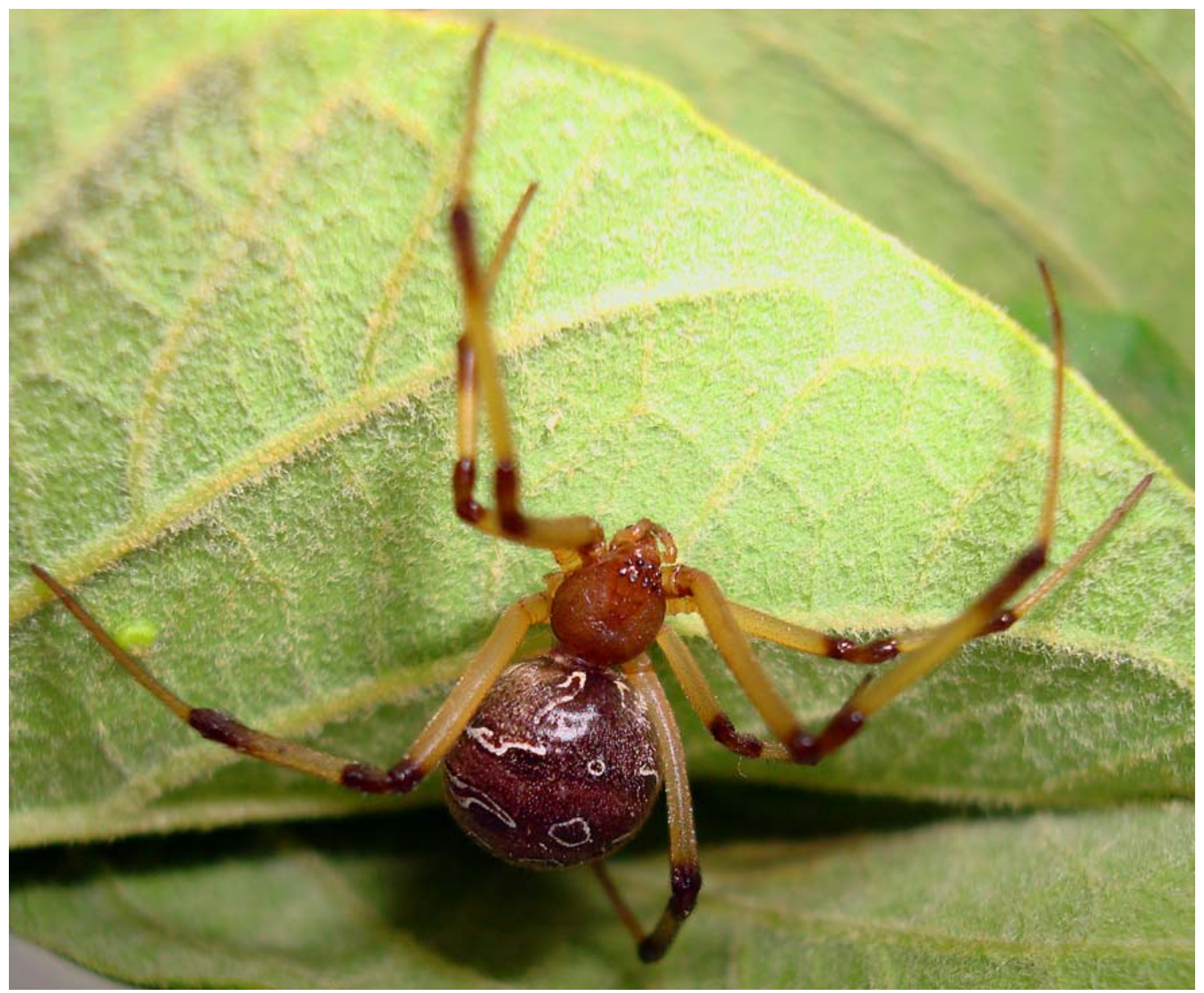

Figure 3. Latrodectus geometricus spider (brown widow). 
Table 1. Laboratory tests at patient admission (day 1) and after discharge from the hospital (day 3)

\begin{tabular}{|c|c|c|c|}
\hline Test & Day 1 & Day 3 & $\begin{array}{l}\text { Reference } \\
\text { values }\end{array}$ \\
\hline Leukocytes $\left(/ \mathrm{mm}^{3}\right)$ & 8900 & 7000 & $4000-11000$ \\
\hline Band cells $\left(/ \mathrm{mm}^{3}\right)$ & 178 & 0 & $40-400$ \\
\hline Neutrophil $\left(/ \mathrm{mm}^{3}\right)$ & 7654 & 3696 & $2000-8000$ \\
\hline Lymphocytes $\left(/ \mathrm{mm}^{3}\right)$ & 890 & 2702 & $1000-5000$ \\
\hline Monocytes $\left(/ \mathrm{mm}^{3}\right)$ & 178 & 392 & $100-1000$ \\
\hline Eosinophils $\left(/ \mathrm{mm}^{3}\right)$ & 0 & 182 & $0-500$ \\
\hline Basophils $\left(/ \mathrm{mm}^{3}\right)$ & 0 & 28 & $0-200$ \\
\hline Hemoglobin (g/dL) & 15 & 13.1 & $12-16$ \\
\hline Hematocrit (\%) & 43 & 38 & $37-47$ \\
\hline Platelets $\left(\times 10^{3} / \mathrm{mm}^{3}\right)$ & 250 & 168 & $140-440$ \\
\hline $\mathrm{ALT}(\mathrm{U} / \mathrm{L})$ & 29 & - & $9-52$ \\
\hline AST (U/L) & 23 & - & $14-36$ \\
\hline Unconjugated bilirubin (mg/dL) & 1.3 & 0.8 & $0.0-1.1$ \\
\hline Conjugated bilirubin (mg/dL) & 0.0 & 0.0 & $0.0-0.3$ \\
\hline Alkaline phosphatase - ALP (U/L) & 57 & - & $36-126$ \\
\hline GGT (U/L) & 21 & - & $12-43$ \\
\hline Lactate dehydrogenase - LDH(U/L) & 443 & - & $313-618$ \\
\hline CPK (U/L) & 74 & - & $30-135$ \\
\hline Creatine (mg/dL) & 0.7 & 0.7 & $0.7-1.2$ \\
\hline Urea $(\mathrm{mg} / \mathrm{dL})$ & 27 & 28 & $15-37$ \\
\hline Sodium (mg/dL) & 141 & - & $137-145$ \\
\hline Potassium (mg/dL) & 4.1 & - & $3.6-5.0$ \\
\hline Calcium (mg/dL) & 9.7 & - & 8.4-10.2 \\
\hline Magnesium (mg/dL) & 2.1 & - & $1.6-2.3$ \\
\hline C-reactive protein $(\mathrm{mg} / \mathrm{dL})$ & 0.0 & - & $\leq 1.0$ \\
\hline VHS (mm/h) & 5 & - & $\leq 20$ \\
\hline Prothrombin time $(\%)$ & 76.1 & 96 & $70-100$ \\
\hline Partial thromboplastin activation time & 0.7 & 0.91 & $\leq 1.25$ \\
\hline Urine & No change & No change & No change \\
\hline
\end{tabular}

Meanwhile pain was severe, there was only local sweating. Specific antivenom or calcium gluconate was not utilized since there were no systemic clinical changes. The skin lesion improved as expressed by reduced redness and swelling, leaving only 
one $5.0 \mathrm{~cm}$ violet blemish. After two days, laboratory tests were normal and the patient was discharged and monitored in our outpatient service.

\section{DISCUSSION}

Latrodectism is the envenomation by spiders belonging to the genus Latrodectus (Araneae: Theridiidae) and is associated with neurotransmitter discharge, particularly in the autonomic system $(8,9)$. Globally, several Latrodectus species are responsible for severe arachnidism because of the high toxicity of their venoms $(10,11)$.

It is important to determine evidence in clinical toxinology, in which a spider bite case meets the following criteria (12):

- clinical effects at the time of the bite;

- the spider being caught immediately after the bite;

- expert identification of the animal.

Morphologically, Latrodectus genus presents an hourglass shaped red/orange spot on the lower part of the globular abdomen, four pairs of eyes positioned in two parallel rows and, "comb feet" i. e., a comblike row of bristles on the tarsi of the hind legs which are used for flinging silk over its prey. Latrodectus females are more venomous and significantly larger than males (leg spans of 30 to $40 \mathrm{~mm}$ compared with 16 to $20 \mathrm{~mm}$ ). Males are also capable of biting but rarely inflict severely venomous bites $(13,14)$. It is a common spider in some regions of Brazil and also along some other parts of the eastern coast of South America and in South Africa (15). Latrodectus geometricus (brown widow), L. curacaviensis (flamenguinha) and $L$. mactans (black widow) can be found in Brazil.

Spiders of the Latrodectus genus have sedentary habits and weave irregular webs. In Brazil, they are found on lawns and in peridomestic areas, parks, empty cans, old tires. Typically, they do not present aggressive behavior and accidents occur, commonly, if the spider is pressed against the victim's body. In general, patient ages range from 10 to 40 years old and the bite usually occurs on the upper limbs (16).

The venom of Latrodectus spider contains a neurotoxin between 120 and $130 \mathrm{kDa}$ known as a-LTX, which strongly binds to a specific presynaptic receptor creating ionic pores, thus provoking a massive release of neurotransmitters. It displays no selectivity for specific synapse types, has no effect on non-neuronal cell types, whether excitable or not, and produces no detectable enzymatic activity $(17,18)$. The 
massive release of the two main peripheral neurotransmitters, acetylcholine and noradrenaline, accounts for the entire clinical picture of latrodectism (19-21).

A retrospective analysis of latrodectism in Bahia state, Brazil, from 1980 to 1990 by Lira da Silva et al. (16) reported that most (57\%) widow bites occurred in cities, affected predominantly men $(70 \%)$ and were inflicted by L. curacaviensis. The clinical presentation was characterized by limb pain (29\%), tremor and rigidity $(29 \%)$, generalized sweating (28\%), distal paresthesia (21\%) and abdominal cramps (17\%). Treatment was mainly supportive $(67 \%)$ but $21 \%$ of widow bite victims required antivenom therapy, with most patients (64\%) being discharged within 24 hours.

It is evident that black widow spider bites cause a more severe form of envenomation than brown widow ones, characterized by generalized muscle pain and cramps, abdominal muscle rigidity, profuse sweating, elevated blood pressure and tachycardia (22). Accidents caused by Latrodectus geometricus usually present only local symptoms and tend to be restricted to the bite site and its surrounding tissue, as described in this case. Only symptomatic treatment was provided for pain and inflammation according to the literature $(5,7,23)$. Administration of specific antiserum and/or calcium gluconate was not necessary $(19,24)$.

There are no tests to confirm the diagnosis of latrodectism. However, if the patient brings the spider, the diagnosis is not so difficult. Since the bite site and symptoms could be nonspecific, the anamnesis is important to proper diagnosis and treatment $(2,25)$. Conditions that should be considered in the differential diagnosis include cytotoxic spider bite, scorpion sting, snakebite, acute abdominal conditions, myocardial infarction, alcohol withdrawal and organophosphate poisoning (22).

In Latrodectus mild envenomation, the recommended treatment is calcium gluconate, muscle relaxants and narcotic analgesics. Some clinicians advocate administering antivenom only in severe cases due to the risk of allergic reactions (26-28).

The description of accidents caused by Latrodectus geometricus may help physicians to properly manage this type of envenomation.

\section{REFERENCES}

1. Platnick NI. The world spider catalog, version 9.0. American Museum of Natural History; 2008. [cited 2008 Out 28]. Available from: http://research.amnh.org/entomology/spiders/catalog/index.html. 
2. Vetter RS, Isbister GK. Medical aspects of spider bites. Annu Rev Entomol. 2008;53:409-29.

3. White J, Warrell D, Eddleston M, Currie BJ, Whyte IM, Isbister GK. Antivenoms. Clin Toxicol. 2003;41(3):263-76.

4. Orlova EV, Rahman MA, Gowen B, Volynski KE, Ashton AC, Manser C, van Heel M, Ushkaryov YA. Structure of a-latrotoxin oligomers reveals that divalent cationdependent tetramers form membrane pores. Nature Structural Biology. 2000;7(1):4853.

5. Ushkaryov YA, Rohou A, Sugita S. Alpha-latrotoxin and its receptors. Handb Exp Pharmacol. 2008;184:171-206.

6. Shukla S, Gour Broome V. First report of the brown widow spider, Latrodectus geometricus C. L. Koch (Araneae: Theridiidae) from India. Curr Sci. 2007;93(6):7757.

7. Cardoso JLC, Brescovit AD, Haddad Jr V. Clinical aspects of human envenoming caused by Latrodectus geometricus (Theridiidae). J Venom Anim Toxins Incl Trop Dis. 2003;9(2):418.

8. Souza AR, Bührnheim PF, Lima CS. Relato de um caso de latrodectismo ocorrido em Manaus, Amazonas, Brasil. Rev Soc Bras Med Trop. 1998;31(1): 95-8.

9. Grishin EV. Black widow spider toxins: the present and the future. Toxicon. 1998;36(11):1693-701.

10. Schenone H. Cuadros tóxicos producidos por mordeduras de araña en Chile: latrodectismo y loxoscelismo. Rev méd Chile. 2003;131(4):437-44.

11. Reyes P, Bozan F, Benabente R, Apt Baruch W, Zulantay Alfaro I. Loxoscelismo y latrodectismo en una paciente: caso clínico. Parasitol latinoam. 2002;57(3-4):15860.

12. Isbister GK. Data collection in clinical toxinology: debunking myths and developing diagnostic algorithms. J Toxicol Clin Toxicol. 2002;40(3):231-7.

13. Maretic Z. Latrodectism: variations in clinical manifestations provoked by Latrodectus species of spiders. Toxicon. 1983;21(4):457-66.

14. Diaz JH, Leblanc KE. Common spider bites. Am Fam Physician. 2007;75(6): 869-73.

15. Brown KS, Necaise JS, Goddard J. Additions to the known U.S. distribution of Latrodectus geometricus (Araneae: Theridiidae). J Med Entomol. 2008;45(5): 959-62. 
16. Lira-da-Silva RM, Matos GB, Sampaio RO, Nunes TB. Retrospective study on Latrodectus stings in Bahia, Brazil. Rev Soc Bras Med Trop. 1995;28(3): 205-10.

17. Scheer $\mathrm{H}$, Meldolesi J. Purification of the putative alpha-latrotoxin receptor from bovine synaptosomal membranes in an active binding form. EMBO J. 1985;4(2):3237.

18. Meldolesi J, Scheer H, Madeddu L, Wanke E. Mechanism of action of alphalatrotoxin: the presynaptic stimulatory toxin of the black widow spider venom. Trends Pharmacol Sci. 1986;7:151-5.

19. Muller GJ. Black and brown widow spider bites in South Africa. A series of 45 cases. S Afr Med J. 1993;83(6):399-405.

20. Nicholson GM, Graudins A. Spiders of medical importance in the Asia-Pacific: atracotoxin, latrotoxin and related spider neurotoxins. Clin Exp Pharmacol Physiol. 2002;29:785-94.

21. Rash LD, Hodgson WC. Pharmacology and biochemistry of spider venoms. Toxicon. 2002;40(4):225-54.

22. Clark RF, Wethern-Kestner S, Vance MV, Gerkin R. Clinical presentation and treatment of black widow envenomation: a review of 163 cases. Ann Emerg Med. 1992;21(7):782-7.

23. Kiriakos D, Núñez P, Parababire Y, García M, Medina J, Sousa LD. First case of human latrodectism in Venezuela. Rev Soc Bras Med Trop. 2008;41(2):202-4.

24. Graudins A, Padula M, Broady K, Nicholson GM. Red-back spider (Latrodectus hasselti) antivenom prevents the toxicity of widow spider venoms. Ann Emerg Med. 2001;37(2):154-60.

25. Miller TA. Latrodectism: bite of the black widow spider. Am Fam Physician. 1992;45(1):181-7.

26. Daly FF, Hill RE, Bogdan GM, Dart RC. Neutralization of Latrodectus mactans and $L$. hesperus venom by redback spider ( $L$. hasseltii) antivenom. J Toxicol Clin Toxicol. 2001;39(2):119-23.

27. Russell FE, Marcus P, Streng JA. Black widow spider envenomation during pregnancy. Toxicon. 1979;17(2):188-9.

28. Goddard J, Upshaw S, Held D, Johnnson K. Severe reaction from envenomation by the brown widow spider, Latrodectus geometricus (Araneae: Theridiidae). South Med J. 2008;101(12):1269-70. 